\title{
EFFECT OF BODY WEIGHT OF GOATS AND LACTATION ORDER ON THE GROWTH RATE OF KIDS IN THE SUCKLING PERIOD
}

\author{
M. Žujović ${ }^{1}$, N. Memiši ${ }^{2}$, V. Bogdanović ${ }^{3}, Z$. Tomić ${ }^{1}$, N. Maksimović ${ }^{1}$, Z. \\ Bijelić $^{1}$, G. Marinkov ${ }^{1}$
}

${ }^{1}$ Institute for Animal Husbandry, Autoput 16, 11080, Belgrade-Zemun, Republic of Serbia

${ }^{2}$ AD Mlekara, Tolminska 10, 24000 Subotica, Republic of Serbia

${ }^{3}$ Faculty of Agriculture, Belgrade - Zemun, Republic of Serbia

Corresponding author: memisin@mlekara.rs

Original scientific paper

Abstract: The paper presents results of investigation of milk yield by lactation, by order, and mother's body weight on growth rate of kids of the domestic Balkan goat. Daily weight gains of 376 single kids (168 male and 208 female), in three monthly intervals, and their final body weight at 90 days of age were established. Variability of analyzed traits was presented using descriptive statistics parameters, and differences of growth traits for weight gain of kids resulting from the effect of milk yield of female goats by order of lactation were investigated by single analysis of variance. The effect of independent variables, mothers' milk yield and body weight, on body weight of kids was tested using multiple regression analysis. During the entire suckling period, established average values for kids body weight differed significantly $(\mathrm{P}<0.001)$, increasing from the $1^{\text {st }}$ toward later lactations. At 90 days of age the lowest values were established in kids from the youngest mothers $(11.86 \mathrm{~kg})$, while for kids of mothers in the fourth or later lactations these values were higher $(13.93 \mathrm{~kg})$. Coefficients of determination indicate that the variability percentage for individual growth traits of kids was in the $0.08-0.17$ interval, indicating its significance. Both "b" coefficients $\left(b_{1}\right.$ and $\left.b_{2}\right)$ are positive and statistically highly significant, except for coefficient $b_{2}$ in the analysis of body weight of kids at birth. The positive sign and high statistical significance indicate a pronounced effect of mother's milk yield and body weight on the body weight of kids up to 90 days of age.

Key words: kids, growth traits, lactation order, body weight, milk yield 


\section{Introduction}

The domestic Balkan goat is predominantly reared in hilly-mountainous regions, and to a somewhat lesser degree in lowlands of Serbia, with predominantly extensive and semi-intensive rearing systems. However, the transition from the to date extensive to intensive goat production is by no means easy or simple, because farmers are still of the opinion that the goat is a species with modest requirements, and that as such it offers modest income. However, the practice of maintaining goat breeding at the level of extensive production, has no future. Therefore, if adequate rearing systems are implemented, and if the technology of production is simultaneously changed, primarily if nutrition and care are improved, goats can contribute to a more profitable production of animal products which are otherwise in very short supply in the nutrition of the population, both in our country, and globally (Dubeuf et al., 2004; Boyazoglu et al., 2005).

In our country there is a widespread opinion that goat breeding should be developed in the direction of increasing milk and meat production via the increase of the number of kids per litter. However, the small number of goats (according to date from the Institute for Animal Husbandry - Belgrade, in 2005 there were 318,000 goats in Serbia), could be substantially increased by more modern housing systems and more rational utilization of the existing number of goats, especially by a more intensive rearing of kids. The current practice of rearing kids, where kids are mostly fed mother's milk with minimum supplementation with cereals and meadow hay, is not providing the optimum level and profitability of such production. Having in mind that the growth rate of kids during the suckling period can be considerably increased, this would decrease rearing costs and provide better profit for farmers.

It should be kept in mind that that the body weight of kids at birth, as well as their weight gain, are defined not only by their individual genetic potential, but also influenced by the mother, as well as by numerous other environmental factors (Mandal et al., 2006). For this reason, mother's milk yield and body weight are considered as important maternal traits significant for the growth of kids.

Since kids supply considerable quantities of best quality meat, and in view of the fact that the body weight of kids in the suckling period is one of the most important phases in the rearing of offspring, the goal of this research was to analyze basic growth characteristics of kids of the domestic Balkan goat in the suckling period, up to 90 days of age, as well as to establish the effect of mother's lactation order, i.e. her milk yield and body weight on the growth of kids. 


\section{Materials and Methods}

In order to investigate the growth rate of kids of the Balkan goat relevant to the lactation milk yield and body weight of their mothers, a total of 376 single kids were weighted during the suckling period (by lactations: $91-1^{\text {st }}, 82-2^{\text {nd }}, 104-$ $3^{\text {rd }}$, and $99-4^{\text {th }}$ and later lactations). Kids were weighted individually, at birth, as well as after 30, 60 and 90 days. A mobile technical balance (10 g accuracy) was used to weight the kids every 10 days, and the body weight established on measuring date was calculated to 30,60 and 90 days of age. Based on registered body weights of kids by individual growth periods, average daily weight gain was calculated.

The variability of analyzed traits is presented using descriptive statistics parameters, while differences of the trait of growth rate of kids resulting from the influence of milk yield in individual lactations by order were investigated using single analysis of variance. Significance of differences was established by LSD test. The effect of independent variables, mother's milk yield and body weight, on growth rate traits of kids as dependent variables, were investigated using multiple regression analysis.

\section{Results and Discussion}

Table 1 presents the body weight of kids at birth, at 30,60 and 90 days of age, total weight gain from birth to 90 days, as well as average daily weight gain, relevant to mother's lactation milk yield by lactation order.

Table 1 shows that milk yield per lactation order had a highly significant $(\mathrm{P}<0.001)$ effect on the body weight of kids at birth, as well as at 30,60 and 90 days of age, and that body weight increased from the $1^{\text {st }}$ toward the $4^{\text {th }}$ lactation of the mother. This is especially pronounced for body weight of kids at 90 days of age, i.e. the average body weight of kids from mothers in the $1^{\text {st }}$ lactation was 11.86 $\mathrm{kg}$, while average body weights of kids from mothers in the $3^{\text {rd }}$ and $4^{\text {th }}$ lactation were 13.28 and $13.93 \mathrm{~kg}$, respectively. Results of analysis of variance confirmed the positive effect of lactation order on the growth of kids up to 90 days, as can be seen also from differences of LSD test between the $1^{\text {st }}$ and $4^{\text {th }}$ and later lactations (Table 1). To a large extent, this can be explained by the higher body weight of kids at birth from older female goats, as well as the higher milk yield of their mothers, compared to mothers in their $1^{\text {st }}$ lactation, which undoubtedly has a high effect on a more intensive growth rate of kids and the higher body weight at weaning. 
Table 1. Descriptive statistical indicators for traits of growth rate of kids up to 90 days of age depending on lactation milk yield by lactation order

\begin{tabular}{|c|c|c|c|c|c|c|c|c|c|c|}
\hline \multirow{2}{*}{ Trait } & \multirow{2}{*}{$\begin{array}{l}\text { Lactation } \\
\text { order }\end{array}$} & \multirow{2}{*}{$\mathrm{N}$} & \multirow{2}{*}{ Average } & \multirow{2}{*}{ SD } & \multirow{2}{*}{ Min } & \multirow{2}{*}{ Max } & \multicolumn{4}{|c|}{ Lactation order (LSD test) } \\
\hline & & & & & & & 1 & 2 & 3 & 4 \\
\hline \multirow{5}{*}{$\begin{array}{l}\text { BW at } \\
\text { birth }(\mathrm{kg})\end{array}$} & 1 & 91 & 2.25 & 0.54 & 1.10 & 3.90 & - & $* * *$ & $* * *$ & $* * *$ \\
\hline & 2 & 82 & 2.61 & 0.47 & 1.50 & 4.20 & $* * *$ & - & N.S. & N.S \\
\hline & 3 & 104 & 2.68 & 0.48 & 1.60 & 3.95 & $* * *$ & N.S. & - & N.S \\
\hline & 4 & 99 & 2.74 & 0.44 & 1.90 & 4.10 & $* * *$ & N.S.. & N.S. & - \\
\hline & Average & - & 2.58 & 0.52 & 1.10 & 4.20 & - & - & - & - \\
\hline \multirow{5}{*}{$\begin{array}{l}\text { BW at } 30 \\
\text { days }(\mathrm{kg})\end{array}$} & 1 & 91 & 5.66 & 0.84 & 3.74 & 8.49 & - & *** & $* * *$ & $* * *$ \\
\hline & 2 & 82 & 6.13 & 0.97 & 4.26 & 8.80 & $* * *$ & - & N.S. & $* * *$ \\
\hline & 3 & 104 & 6.39 & 0.94 & 4.67 & 9.62 & $* * *$ & N.S.. & - & $* * *$ \\
\hline & 4 & 99 & 6.74 & 1.02 & 4.72 & 9.33 & $* * *$ & $* * *$ & $* * *$ & - \\
\hline & Average & - & 6.25 & 1.02 & 3.74 & 9.62 & - & - & - & - \\
\hline \multirow{5}{*}{$\begin{array}{l}\text { BW at } 60 \\
\text { days }(\mathrm{kg})\end{array}$} & 1 & 91 & 8.88 & 1.15 & 6.06 & 12.72 & - & $* * *$ & $* * *$ & $* * *$ \\
\hline & 2 & 82 & 9.50 & 1.37 & 6.51 & 13.30 & $* * *$ & - & $* * *$ & $* * *$ \\
\hline & 3 & 104 & 10.03 & 1.34 & 7.16 & 14.67 & $* * *$ & $* * *$ & - & $* * *$ \\
\hline & 4 & 99 & 10.51 & 1.53 & 7.15 & 14.70 & $* * *$ & $* * *$ & $* * *$ & - \\
\hline & Average & - & 9.76 & 1.48 & 6.06 & 14.70 & - & - & - & - \\
\hline \multirow{5}{*}{$\begin{array}{l}\text { BW at } 90 \\
\text { days }(\mathrm{kg})\end{array}$} & 1 & 91 & 11.86 & 1.39 & 8.58 & 16.56 & - & $* * *$ & $* * *$ & $* * *$ \\
\hline & 2 & 82 & 12.60 & 1.64 & 9.06 & 17.30 & $* * *$ & - & $* * *$ & $* * *$ \\
\hline & 3 & 104 & 13.28 & 1.61 & 9.59 & 18.73 & $* * *$ & $* * *$ & - & $* * *$ \\
\hline & 4 & 99 & 13.93 & 1.77 & 9.82 & 19.03 & $* * *$ & $* * *$ & $* * *$ & - \\
\hline & Average & - & 12.96 & 1.78 & 8.58 & 19.03 & - & - & - & - \\
\hline \multirow{5}{*}{$\begin{array}{l}\text { Weight } \\
\text { gain, } \\
0-90 \text { days } \\
(\mathrm{kg})\end{array}$} & 1 & 91 & 9.61 & 1.11 & 6.78 & 12.66 & - & N.S. & $* * *$ & $* * *$ \\
\hline & 2 & 82 & 10.01 & 1.37 & 7.05 & 13.80 & N.S. & - & $* * *$ & $* * *$ \\
\hline & 3 & 104 & 10.60 & 1.39 & 7.29 & 15.13 & $* * *$ & $* * *$ & - & $* * *$ \\
\hline & 4 & 99 & 11.14 & 1.55 & 7.47 & 15.88 & $* * *$ & $* * *$ & $* * *$ & - \\
\hline & Average & - & 10.38 & 1.49 & 6.78 & 15.88 & - & - & - & - \\
\hline \multirow{5}{*}{$\begin{array}{l}\text { ADWG } \\
\text { from } \\
0-90 \text { days } \\
(\mathrm{kg})\end{array}$} & 1 & 91 & 0.106 & 0.01 & 0.075 & 0.14 & - & N.S. & $* * *$ & $* * *$ \\
\hline & 2 & 82 & 0.111 & 0.02 & 0.078 & 0.15 & N.S. & - & $* * *$ & $* * *$ \\
\hline & 3 & 104 & 0.117 & 0.02 & 0.081 & 0.17 & $* * *$ & $* * *$ & - & $* * *$ \\
\hline & 4 & 99 & 0.124 & 0.02 & 0.083 & 0.18 & $* * *$ & $* * *$ & $* * *$ & - \\
\hline & Average & - & 0.115 & 0.016 & 0.075 & 0.176 & - & - & - & - \\
\hline
\end{tabular}

BW - Body weight; ADWG - Average daily weight gain;

N.S. - $\mathrm{P}>0.05 ; * * *-\mathrm{P}<0.001$;

As for body weights of kids, values of average daily weight gain during the entire suckling period also differed significantly $(\mathrm{P}<0.001)$, growing from the $1^{\text {st }}$ toward later lactations, with the lowest values established in kids from the youngest mothers $(106.5 \mathrm{~g})$, and higher values for kids with mothers in the $4^{\text {th }}$ and later lactations (124 g). Statistically significant differences for daily weight gain of kids were established between the $1^{\text {st }}$ and $3^{\text {rd }}$, and $1^{\text {st }}$ and $4^{\text {th }}$ lactation, while the difference between the $1^{\text {st }}$ and the $2^{\text {nd }}$ lactation was not statistically significant. Faster development of kids requires mothers near the end of their own body development. 
Table 2 presents multiple regression analysis coefficients for the effect of body weight and milk yield of goats on the growth of their kids up to 90 days of age.

Table 2. Multiple regression analysis of effect of mother's body weight and milk yield on the body weight of kids up to 90 days of age

\begin{tabular}{|l|c|c|c|c|}
\hline \multirow{2}{*}{ Trait } & \multirow{2}{*}{$\begin{array}{c}\mathrm{R}^{2} \text { for } \\
\text { regression } \\
\text { equation }\end{array}$} & \multicolumn{3}{|c|}{ Regression equation parameters and "b" coefficient } \\
\cline { 3 - 5 } significance & Coefficient "a" & $\begin{array}{c}\text { Coefficient "b } \\
\text { (mother's body } \\
\text { weight) }\end{array}$ & $\begin{array}{c}\text { Coefficient "b } \\
\text { (mother's milk } \\
\text { yield) }\end{array}$ \\
\hline BW at birth & 0.08 & 1.777465 & $0.016003^{* * *}$ & $0.000919^{\text {ns }}$ \\
\hline BW at 30 days & 0.12 & 4.381400 & $0.035943^{* * *}$ & $0.002510^{* * *}$ \\
\hline BW at 60 days & 0.14 & 6.794628 & $0.058903^{* * *}$ & $0.003618^{* * *}$ \\
\hline BW at 90 days & 0.17 & 9.129191 & $0.075776^{* * *}$ & $0.004738^{* * *}$ \\
\hline $\begin{array}{l}\text { Weight gain, } \\
\text { 0-90 days }\end{array}$ & 0.14 & 7.428982 & $0.058811^{* * *}$ & $0.003543^{* * *}$ \\
\hline ADWG, 0-90 days & 0.14 & 0.082413 & $0.000646^{* * *}$ & $0.000041^{* * *}$ \\
\hline
\end{tabular}

BW - Body weight; ADWG - Average daily weight gain;

N.S. - $\mathrm{P}>0.05 ; * * *-\mathrm{P}<0.001$;

Results presented in Table 2 show that multiple regression determination coefficients are in the interval between 0.08 and 0.17 , i.e. the significance of investigated independent variables. Both " $b$ " coefficients $\left(b_{1}\right.$ and $\left.b_{2}\right)$ are positive and statistically highly significant for all growth rate traits, except coefficient $b_{2}$ for the analysis of body weight of kids at birth, as is also expected biologically. The positive sign and high statistical significance indicate a pronounced effect of mother's milk yield and body weight on growth of kids up to 90 days of age. In order to achieve the adequate age structure within the flock, this should be kept in mind when planning production of kids.

In investigations by Labrouca et al. (2010) on a local breed of goat reared in Tunisia, the lactation order of goats had no statistically significant effect on the body weight of kids at birth and at 30 days of age. However, investigations by other authors (Djemali et al., 1994; Venzhbong et al., 2005; Najari, 2005) state that the effect of lactation order on achieved body weight of kids in the suckling period to large extent depends on the mother' milk yield, with a direct effect on the body weight of kids, which was also confirmed by results obtained in this investigation. Djemali et al. (1994) state that the body weight of kids depends on lactation order, and increases for goats up to lactation 5, as well as that it decreases for later lactations. In addition, Portolano et al. (2002), state that mother's lactation order had a significant effect on the body weight of kids in the suckling period, i.e. up to 60 days of age. Authors also conclude that kids from older mothers are heavier at birth, but not for mothers of 8 to 10 years of age. Bogdanović et al. (2006) state that both mother's lactation order and milk yield had a statistically significant and 
positive effect on the growth of kids up to 90 days of age. On the other hand, investigations by Al Shorepi et al. (2002) established no statistically significant influences of the age of mothers on the growth rate of kids.

\section{Conclusion}

Results established in investigations of growth rate traits of kids of the domestic Balkan goat permit following conclusions:

Lactation milk yield had a highly significant $(\mathrm{P}<0.001)$ effect on the body weight of kids at birth, as well as on body weight at 30,60 and 90 days of age, with body weight increasing from the $1^{\text {st }}$ to the $4^{\text {th }}$ lactation. Up to 90 days, kids from mothers in their $1^{\text {st }}$ lactation had an average body weight of $11.86 \mathrm{~kg}$, while for kids from mothers in their $3^{\text {rd }}$ and $4^{\text {th }}$ lactation this was 13.28 and $13.93 \mathrm{~kg}$ respectively.

Like established body weights of kids, values of average daily weight gain throughout the suckling period also significantly differed $(\mathrm{P}<0.001)$, and increased from the $1^{\text {st }}$ toward later lactations, with lowest values for kids from the youngest mothers $(106.5 \mathrm{~g})$, and highest values for kids from mothers in the $4^{\text {th }}$ and later lactations (124 g).

Analysis of variance confirmed the biologically positive effect of milk yield by lactation order on the growth of kids up to 90 days.

The effect of mother's milk yield and body weight on growth rate traits of kids was analyzed using multiple regression analysis, and indicates high statistical significance and pronounced effect of these two independent variables on the growth of kids up to 90 days of age.

Having in mind that most best quality meat is produced by kids, and in view of the fact that the body weight of kids in the suckling period is one of the most important phases in the rearing of offspring in goat breeding, much more attention must be devoted to nutrition of both female goats and kids, as well as to providing favorable conditions for their housing and care.

\section{Acknowledgment}

Research was financed by the Ministry of Education and Science, Republic of Serbia, project TR-31053. 


\title{
Uticaj telesne mase koza i laktacije po redu na porast jaradi u dojnom periodu
}

\author{
M. Žujović, N. Memiši, V. Bogdanović, Z. Tomić, N. Maksimović, Z. Bijelić, G. \\ Marinkov
}

\section{Rezime}

U ovom radu prikazani su rezultati ispitivanja uticaja količine mleka $u$ laktaciji po redu, i telesne mase majke na porast jaradi domaće balkanske koze do 90 dana. U cilju ispitivanja razvoja telesne mase jaradi u zavisnosti od količine mleka u laktaciji po redu u toku dojnog perioda ukupno je izmereno 376 jaradi jedinaca (168 muških i 208 ženskih). Varijabilnost analiziranih osobina je prikazana parametrima deskriptivne statistike, dok su razlike u osobinama porasta jaradi koje su nastale pod uticajem mlečosti koza u laktaciji po redu, ispitivane jednostrukom analizom varijanse. Višestruko regresionom analizom ispitivan je uticaj nezavisno promenljivih veličina, mlečnost majke i telesna masa majke, na porast jaradi.

Utvrđene vrednosti telesnih masa u toku čitavog dojnog perioda značajno su se razlikovale $(\mathrm{P}<0,001)$ i povećavale od prve ka kasnijim laktacijama, pri čemu su u uzrastu od 90 dana najmanje vrednosti utvrđene kod jaradi od najmlađih koza $(11,86 \mathrm{~kg})$, dok su kod jaradi čije su majke bile u četvrtoj i kasnijim laktacijama te vrednosti iznosile $13,93 \mathrm{~kg}$. Koeficijenti determinacije ukazuju na to da se procenat varijabilnosti pojedinih osobina porasta jaradi nalazio $u$ intervalu od 0,08 do 0,17 , što ukazuje na njihovu značajnost. Oba „, $b^{“}$ koeficijenta $\left(b_{1}\right.$ i $\left.b_{2}\right)$ su pozitivna $i$ statistički visoko značajna, osim koeficijenta $b_{2} u$ analizi telesne mase jaradi pri rođenju. Pozitivni predznak i visoka statistička značajnost ukazuju na izražen uticaj mlečnosti i telesne mase majki na porast jaradi do 90 dana.

\section{References}

AL-SHOREPY S.A., ALHADRAMI G.A., ABDULWAHA K. (2002): Genetic and phenotypic parameters for early growth traits in Emirati goat. Small Rumin. Res., 45, 217-223.

BOGDANOVIĆ V., MEMIŠI N., BAUMAN F. (2006): Factors affecting growth of the Balkan goat kids from birth to 90 days. 57th Annual Meeting of the EAAP, Book of abstracts, 12, 217.

BOYAZOGLU J., HATZIMINAOGLOU I., MORAND-FEHR P. (2005): The role of the goat in society: past, present and perspectives for the future. Small Rumin. Res., 60, 13-23. 
CASTEL J.M., RUIZ F.A., MENA Y., SANCHEZ-RODRIGUEZ M. (2010): Present situation and future perspectives for goat production systems in Spain. Small Rumin. Res., 89, 207-210.

DUBEUF J.P., MORAND-FEHR P., RUBINO R. (2004): Situation, changes and future of goat industry around the world. Small Rumin. Res., 51, 165-173.

DJEMALI M., ALOULOU R., BEN SASSI M. (1994): Adjustment factors and genetic and phenotypic parameters for growth traits of Barbarine lambs in Tunisia. Small Rumin. Res., 13, 41-47.

MANDAL A., NESER F.W.C., ROUT P.K., ROY R., NOTTER D.R. (2006): Estimation of direct and maternal (co)variance components for pre-weaning growth traits in Muzaffarnagari sheep. Livest. Sci., 99, 79-89.

MABROUK O., NAJARI S., COSTA R.G., AMOR G., AMEL B.A.E., DELGADO J.V. (2010): The effect of non-genetic factors on the early body weights of Tunisian local goats. R. Bras. Zootec., 39, 5, 1112-1117.

NAJARI S. (2005): Zootechnical and genetic characterization of a caprine population. Case of the local caprine population of the Tunisian arid areas. $214 \mathrm{f}$. Thesis (Ph D. in Agronomy) - Institut National Agronomique de Tunis, Tunisia.

PORTOLANO B., TODARO M., FINOCCHIARO R. (2002): Estimation of the genetic and phenotypic variance of several growth traits of the Sicilian Girgentana goat. Small Rumin. Res., 45, 247-253.

STATISTIČKI GODIŠNJAK SRBIJE (2005): RS Republički zavod za statistiku, 3-425.

WENZHONG L., YUAN Z., ZHONGXIAO Z. (2005): Adjustment for non-genetic effects on body weight and size in Angora goats. Small Rumin. Res., 59, 25-31. 